\title{
Retained placenta in Friesian mares: reproductive performance after foal heat breeding versus breeding in a subsequent heat
}

\author{
M. Sevinga ${ }^{1}$, H.W. Barkema ${ }^{2}$ and J.W. Hesselink ${ }^{3}$ \\ 'Veterinary Practice Mid-Fryslân, Akkrum, The Netherlands; ${ }^{2}$ Animal Health Service, Drachten, The Netherlands; \\ ${ }^{3}$ University Hospital Groningen, Groningen, The Netherlands
}

\begin{abstract}
Summary
Postpartum reproductive performance was studied in 54 Friesian brood mares with and 50 without retained placenta. Retained placenta was defined as failure to expel all fetal membranes within 3 hours after the delivery of the foal. The group of mares with retained placenta was subdivided into mares in which the placenta had been removed manually $(n=30)$ and mares in which it was not $(n=24)$. Within each group, reproductive performance after breeding in the foal heat and breeding in a subsequent heat was compared.

Age of the mares, number of mares treated with antibiotics after insemination, and number of mares treated with prostaglandins were recorded. The interval between delivery and conception, efficacy rate, seasonal pregnancy rate, pregnancy rate after first insemination, pregnancy loss rate, and foaling rate did not differ between the mares with and without retained placenta or between the mares with and without manual removal of the retained placenta. Within each group, the pregnancy rate after first insemination did not differ between breeding for the first time in the foal heat and breeding for the first time in a subsequent heat.

It is concluded that reproductive performance did not differ between 1) Friesian mares with and without retained placenta and, 2) Friesian mares with and without manual removal of the placenta. With regard to reproductive performance, retained placenta and manual removal of the placenta are not valid reasons to avoid foal heat breeding in Friesian mares.
\end{abstract}

Keywords: $\quad$ retained placenta, reproductive performance, Friesian mares.

\section{Retentio secundinarum bei Friesenstuten: Fertilität bei Besamung in der Fohlenrosse im Vergleich zur Besamung während späterer Rossen}

Bei 54 Friesenstuten mit und 50 ohne Retentio secundinarum wurde die postpartale Fertilität untersucht. Der verzögerte Abgang der Plazenta wurde als mangelnder Abgang aller fetalen Membranen innerhalb von 3 Stunden nach der Geburt des Fohlens definiert. Die Gruppe der Stuten mit verzögertem Plazentaabgang wurde in Stuten mit $(n=30)$ und ohne $(n=24)$ manuelle Abnahme der Plazenta unterteilt. In beiden Gruppen wurde die Fertilität bei Besamung in der Fohlenrosse und in darauffolgenden Rossen verglichen. Das Alter der Stuten, eine antibiotische Behandlung post inseminationem und die Verabreichung von Prostaglandinen wurden protokolliert. Der Zeitraum zwischen Geburt und Konzeption, die Anzahl der notwendigen Besamungen, die saisonale Fertilitätsrate, die Fertilitätsrate nach der ersten Insemination, die Verfohlungsrate und die Abfohlrate unterschieden sich nicht zwischen den Stuten mit und ohne Retentio secundinarum und zwischen den Stuten mit und ohne manueller Plazentaabnahme. In beiden Gruppen entsprach die Trächtigkeitsrate bei erster Besamung in der Fohlenrosse der bei erster Insemination in einer darauffolgenden Rosse. Zusammengefasst kann festgestellt werden, dass die Fertilität sich nicht unterscheidet bei erstens Friesenstuten mit und ohne Nachgeburtsverhaltung und zweitens bei Friesenstuten mit und ohne manueller Plazentaabnahme. Sowohl eine Retentio secundinarum als auch eine manuelle Abnahme der Plazenta sind demnach kein Grund, eine Besamung in der Fohlenrosse zu unterlassen.

Schlüsselwörter : Retentio secundinarum, Reproduktionsparameter, Friesenstuten

\section{Introduction}

As a consequence of the relatively short period which is available between parturition and subsequent pregnancy, in order to realise an interfoaling interval of approximately 12 months, reproductive performance of mares after breeding in the postpartum period has been extensively studied (Ginther, 1992; Blanchard and Varner, 1992). Generally, pregnancy rates after foal heat breeding are lower than pregnancy rates after breeding in other heats (Ginther, 1992; Loy, 1980); however, foal heat breeding does shorten the interval between delivery and conception (Lowis and Hyland, 1991). Results of some studies show higher pregnancy loss rates after breeding in the foal heat compared with breeding in a subsequent heat, although others do not (Badi, 1981; Ball, 1988; Woods, 1987; Loy, 1980). The decreased reproductive performance after foal heat breeding is thought to be related to incomplete uterine involution (Katila, 1988; Gygax, 1979). In order to delay breeding until uterine involution should be complete, and to improve pregnancy rates, administration of prostaglandins, shortening the first postpartum luteal phase, has been performed (Almeida, 1995; Lowis and Hyland, 1991). It has been suggested, not to breed mares with a history of foaling complications or evidence of reproductive tract pathology, at foal heat (Camillo, 1997). Known causes of disturbance of the normal uterine involution are dystocia and retention of the placenta (Vandeplassche, 1983). Retained placenta (RP) in the mare is defined as a failure to expel all fetal membranes within 3 hours after delivery of the foal (Blanchard and Varner, 1993). The incidence of RP varies from 2 to $10 \%$ of foalings (Vandeplassche et al., 1971) although the incidence of RP in Friesian mares in The Netherlands is estimated to be approximately $35 \%$ (W. van der Holst, personal communication). In different breeds of horses, especially in case of RP, decreased pregnancy 
rates after insemination in the foal heat and an increased interval between delivery and conception were found, which were associated with a disturbed involution of the genital system (Glatzel and Belz, 1995; Belz and Glatzel, 1995). However, in Standardbred mares, no difference was found in reproductive performance between mares with and without RP, and in mares with RP no difference in pregnancy rate was reported after breeding in the foal heat versus breeding in other heats (Provencher et al., 1988).

Administration of oxytocin is considered to be the most appropriate systemic treatment for RP in the mare (Threlfall et al., 1987; Perkins, 1999). In the Netherlands, manual removal of the placenta is a frequently performed local treatment, when systemic use of oxytocin has not been successful. After manual removal of the placenta, microretention of chorial villi (Vandeplassche et al., 1972) and damage to the endometrium may occur, leading to a markedly delayed involution of the genital tract (Steven et al., 1979). Microretention may induce an accumulation of cellular debris, favorable for bacterial growth, which may lead to systemic disorders as the metritis/septicemia/laminitis syndrome and a decrease in fertility (Vandeplassche et al., 1983; Threlfall, 1992).

The objectives of the present study were to compare postpartum reproductive performance after foal heat breeding versus breeding in a subsequent heat of 1) Friesian mares with and without RP, and of 2) Friesian mares with RP, with and without manual removal of the placenta, since, to our knowledge, no reports have been published on this subject.

\section{Materials and methods}

\section{Study Population and Treatment Protocol}

In the breeding season of 1999, 104 Friesian brood mares in the practice area of the veterinary practice Mid-Fryslân, The Netherlands, were studied. In this study, retained placenta was defined as a failure to expel all fetal membranes within 3 hours after the delivery of the foal. Fifty mares had shed the placenta within 3 hours and 54 mares exhibited RP. Six mares with RP expelled the placenta spontaneously, before treatment could be started. Forty-eight mares with RP were treated with oxytocin or oxytocin combined with a Ca-Mg-borogluconate solution. Within 2 hours of this treatment, no additional treatment was performed. If the placenta was not expelled within 2 hours, it was removed manually from the uterus $(n=30)$ and the uterus was subsequently flushed with large amounts (50 to 100 litres) of water.

Hundred and three of the 104 mares were artificially inseminated in this breeding season with semen of Friesian stallions of known fertility. One mare was serviced naturally. Pregnancy detection was performed by transrectal ultrasonography on approximately Day 18. The age of the mares, the number of mares which received an intrauterine treatment with antibiotics after insemination, and the number of mares which were treated with prostaglandins i.m. to induce estrus were recorded.

\section{Reproductive Performance Parameters}

The following parameters were used to compare reproductive performance between mares with and without RP and mares with and without manual removal of the placenta: 1) interval between deli- very and conception, defined as the number of days between delivery of the foal and the last insemination that resulted in pregnancy, 2) efficacy rate, defined as the number of served cycles divided by the number of mares that had a positive pregnancy diagnosis in this season, 3) seasonal pregnancy rate, defined as the number of mares that had a positive pregnancy diagnosis in this season, divided by the number of mares bred, 4) pregnancy rate after first insemination in the foal heat (first estrus within 19 days postpartum), or in a subsequent heat, defined as the number of mares pregnant after first insemination in the foal heat or a subsequent heat, respectively, divided by the number of mares bred for the first time in the foal heat or in a subsequent heat, respectively, 5) pregnancy loss rate, defined as the number of mares diagnosed as pregnant but not foaling, increased by the number of mares with a re-established pregnancy and subsequent foaling after initial pregnancy loss, divided by the number of mares that had a positive pregnancy diagnosis in this season, and 6) foaling rate, defined as the number of mares that foaled (confirmed by the owner), divided by the number of mares bred.

Pregnancy rate after first insemination in the foal heat, or in a subsequent heat, and interval between delivery and conception, after first insemination in the foal heat, or in a subsequent heat were used to compare reproductive performance per group of mares after foal heat breeding versus breeding for the first time in a subsequent heat.

\section{Statistical Analysis}

To approximate the normal distribution, a natural logarithm of the interval between delivery and conception was used. The age of the mares, the natural logarithm of the interval between delivery and conception, and the efficacy rate were compared using the Student's t-test. The pregnancy rate, foaling rate, pregnancy loss rate, number of single intrauterine treatments with antibiotics after insemination, and number of mares treated with prostaglandins were analysed, using Pearson's chisquare analysis on contingency tables. If the number of observations was $\leq 25$, Fisher's Exact Test was used for this purpose. Statistical significance was declared at $P<0.05$.

\section{Results}

Frequencies of the studied parameters of mares with and without RP are shown in Table 1. No difference was found between the reproductive performance of Friesian mares with RP or without RP. Eight mares (15\%) with RP received an intrauterine treatment with antibiotics after insemination in the foal heat, compared with 7 mares (14\%) without RP $(P=0.91)$. Seven mares (13\%) with RP were treated with prostaglandins, compared with 7 mares $(14 \%)$ without $R P(P=0.88)$. In 30 mares of the 54 mares with RP (56\%), the placenta was removed manually (in the other mares, the placenta was expelled spontaneously or after treatment with oxytocin or oxytocin combined with a $\mathrm{Ca}-\mathrm{Mg}$-borogluconate solution). Frequencies of the studied parameters within the group of mares with RP, with and without manual removal of the placenta, are shown in Table 2. Manual removal of the placenta did not affect the reproductive performance of Friesian mares with RP (Table 2). Of the mares 
Tab. 1: Reproductive performance parameters of Friesian mares with $(n=54)$ and without $(n=50)$ retained placenta.

Reproduktionsparameter der Friesenstuten mit $(n=54)$ und ohne $(n=50)$ Retentio secundinarum

\begin{tabular}{|l|c|c|c|}
\hline \multicolumn{4}{|c|}{ Group of mares } \\
\hline Parameter & $\begin{array}{c}\text { Retained } \\
\text { placenta }\end{array}$ & $\begin{array}{c}\text { No } \\
\text { retained } \\
\text { placenta }\end{array}$ & P-value \\
\hline $\begin{array}{l}\text { Interval delivery- } \\
\text { conception (days) }\end{array}$ & 27 & 30 & 0.80 \\
\hline Efficacy rate foal heat & 50 & 1.6 & 0.32 \\
\cline { 2 - 5 } Seasonal pregnancy rate (\%) & 93 & 86 & 0.25 \\
\hline $\begin{array}{l}\text { Pregnancy rate (\%) after } \\
\text { first insemination in: }\end{array}$ & 52 & 56 & 0.87 \\
\hline Pregnancy loss rate (\%) & 12 & 11 & 0.83 \\
\hline Foaling rate (\%) & 88 & 82 & 0.42 \\
\hline
\end{tabular}

Tab. 2: Reproductive performance parameters of Friesian mares with retained placenta $(R P)$, with $(n=30)$ and without $(n=24)$ manual removal of the placenta.

Reproduktionsparameter der Friesenstuten mit Retentio secundinarum $(R P)$, mit $(n=30)$ und ohne $(n=24)$ manueller Abnahme der Plazenta

\begin{tabular}{|l|c|c|c|}
\hline \multicolumn{4}{|c|}{ Group of mares with RP } \\
\hline Parameter & $\begin{array}{c}\text { Manual } \\
\text { removal }\end{array}$ & $\begin{array}{c}\text { No } \\
\text { manual } \\
\text { removal }\end{array}$ & P-value \\
\hline $\begin{array}{l}\text { Interval delivery-conception } \\
\text { (days) 1 }\end{array}$ & 30 & 25 & 0.18 \\
\hline Efficacy rate & 1.6 & 1.5 & 0.77 \\
\hline Seasonal pregnancy rate (\%) & 93 & 92 & 0.82 \\
\hline $\begin{array}{l}\text { Pregnancy rate (\%) after first } \\
\text { insemination in: }\end{array}$ & 43 & 56 & 0.48 \\
\cline { 2 - 5 } & 63 & 20 & 0.10 \\
\cline { 2 - 5 } & 10 & 8 & 0.83 \\
\hline Pregnancy loss rate (\%) total & 83 & 92 & 0.36 \\
\hline Foaling rate & & & \\
\hline
\end{tabular}

Tab. 1 und Tab. 2: 'Geometric mean

in which the placenta was removed manually, 6 (20\%) received an intrauterine treatment with antibiotics after insemination in the foal heat and 5 (17\%) were treated with prostaglandins. In the mares in which the placenta was not removed manually, the figures were $2(8 \%)$ and $2(8 \%)$, respectively, $(P=0.23$ and $P=0.37$, respectively). The overall number of intrauterine treatments for the mares in which the placenta was removed manually was 19 (63\%), compared with 6 (25\%) for the mares in which the placenta was not removed manually $(P=0.005)$.

Per group of mares with and without RP, and with and without manual removal of the placenta, reproductive performance parameters of mares inseminated for the first time in the foal heat or in a subsequent heat are given in Table 3.

The interval between delivery and conception differed between mares inseminated for the first time in the foal heat and mares inseminated for the first time in another heat. There was no difference between the pregnancy rate of mares after first insemination in the foal heat or in another heat (Table 3).

The mean age of the mares with and without RP was $8.8 \mathrm{yrs}$. and 9.5 yrs. respectively $(T$-value $=0.92, P=0.36)$, and that of the mares with RP, with and without manual removal, was 8.6 yrs. and 9.0 yrs. respectively ( $T$-value $=0.37, P=0.72)$. Metritis, septicemia, or laminitis was not diagnosed in any of the mares and no additional treatment was given during the study period.

\section{Discussion}

In our study, we did not find any difference in reproductive performance of Friesian mares with RP or without RP. The results are comparable with the findings for Standardbred mares with RP,

Tab. 3: Reproductive performance parameters of Friesian mares, inseminated for the first time in the foal heat or in a subsequent heat, per group of mares with and without RP, and with and without manual removal of the placenta.

Reproduktionsparameter der Friesenstuten, die zum erstenmal in der Fohlenrosse oder in einer darauffolgenden Rosse besamt wurden, pro Gruppe von Stuten mit und ohne RP, und mit und ohne manuelle Abnahme der Plazenta

\begin{tabular}{|c|c|c|c|}
\hline \multicolumn{4}{|c|}{ First insemination in: } \\
\hline $\begin{array}{l}\text { Parameter/group of } \\
\text { mares }\end{array}$ & $\begin{array}{l}\text { Foal heat } \\
\qquad\left(n^{1}\right)\end{array}$ & $\begin{array}{c}\text { Other } \\
\text { heat }\left(n^{1}\right)\end{array}$ & P-value \\
\hline \multicolumn{4}{|l|}{$\begin{array}{l}\text { Interval delivery-conception } \\
\text { (days) }^{2}\end{array}$} \\
\hline \multirow{3}{*}{$\begin{array}{l}\text { manual removal } \\
\text { no manual removal }\end{array}$} & $23(33)$ & $40(18)$ & 0.0006 \\
\hline & $24(14)$ & $40(14)$ & 0.03 \\
\hline & 22 (19) & $41(4)$ & 0.01 \\
\hline without RP & $27(37)$ & $42(7)$ & 0.02 \\
\hline \multicolumn{4}{|l|}{$\begin{array}{l}\text { Pregnancy rate (\%) after first } \\
\text { insemination }\end{array}$} \\
\hline with RP & $50(32)$ & $52(21)$ & 0.87 \\
\hline manual removal & $43(14)$ & $63(16)$ & 0.28 \\
\hline no manual removal & $56(18)$ & $20(5)$ & 0.19 \\
\hline without RP & $44(36)$ & $56(9)$ & 0.55 \\
\hline
\end{tabular}

'Number of mares inseminated; ${ }^{2}$ Geometric mean 
reported by Provencher et al. (1988). In contrast, two German studies reported a decreased reproductive performance after RP in different breeds of horses, associated with a disturbed involution of the genital system (Glatzel and Belz, 1995; Belz and Glatzel, 1995). However, in these studies, mares with RP received an intrauterine treatment with an antiseptic solution, combined with antibiotics, on the first and second day postpartum, which could have interfered with bacterial phagocytosis. In our study, the proportion of mares with RP that received an intrauterine treatment with antibiotics after insemination in the foal heat, or a treatment with prostaglandins, was not different from that of mares without RP. Therefore, the two groups of mares were comparable.

The reproductive performance of mares in which the placenta was removed manually, did not differ from that of mares with RP, without manual removal. Flushing the uterine cavity with large amounts of water after manual removal, and thereby removal of cellular debris and bacteria, may have been beneficial. More mares in which the placenta was removed manually received a single intra uterine treatment with antibiotics after breeding. Although no correlation has been found between bacteriological cultures prepared from uterine swabs before, and embryo recovery rates and pregnancy rates after foal heat breeding, the presence of large numbers of bacteria in uterine swabs might be associated with low pregnancy rates (Huhtinen et al., 1996; Katila et al. 1988). Therefore, we cannot exclude that the mares in which the placenta was removed manually, treated with antibiotics after breeding, may have been favored above mares with RP, without manual removal of the placenta. The two groups of mares were comparable with regard to the percentage of mares treated with prostaglandins.

Within the studied groups, the interval between delivery and conception was different, whereas the pregnancy rate after first insemination between mares inseminated for the first time in the foal heat or in another heat, was not. These results show that, irrespective of RP or manual removal of the placenta, insemination in the foal heat is an effective method for shortening the interval between delivery and conception.

Although reproductive performance decreases with advancing age (Ginther, 1992), we did not find age to be a limiting factor for reproductive performance. Furthermore, older age is apparently no risk factor for equine RP.

In conclusion, the postpartum reproductive performance of Friesian mares with RP was not different from that of Friesian mares without RP. Further, manual removal of the retained placenta did not affect reproductive performance. Despite the widely held belief, based on empiricism, that mares should not be bred during the foal heat after RP and manual removal of the placenta, we found no reason to advice against foal heat breeding in Friesian mares, when using the described protocol.

\section{Literature}

Almeida, F. Q., Fonseca, F. A. and Espechit, C. J. B. (1995): Effects of PGF2 $\alpha$ and progesterone on the reproductive efficiency of crossbred mares during the postpartum period. Rev Soc Brasil Zootec; 24, 652-659

Ball, B. (1988): Embryonic loss in mares: incidence, possible causes and diagnostic considerations. Vet Clin North Am Equine Pract; 4, 263-290
Badi, A. M., O'Byrne, T. M. and Cunningham, E. P. (1981): An analysis of reproductive performance in thoroughbred mares. Irish Vet J; 35, 1-12

Belz, J. P. and Glatzel, P. S. (1995): Fertility in mares after a disturbed as well as an undisturbed puerperium: significance of histological and cytological examinations of the uterus. Tierärztl Prax; 23, 267-272

Blanchard, T. L. and Varner, D. D. (1992): Equine Reproduction $1^{\text {st }}$ ed 622-625 Ed: AO McKinnon, JL Voss, Lea \& Febiger, Philadelphia

Blanchard, T. L. and Varner D. D. (1993): Therapy for retained placenta in the mare. Vet Med; 88, 55-59

Camillo, F., Marmorini, P., Romagnoli, S., Vannozzi, I. and Bagliacca, M. (1997): Fertility at the first post partum estrous compared with fertility at the following estrous cycles in foaling mares and with fertility in nonfoaling mares. J Equine Vet Sci.; 17, 612-616

Ginther, O. J. (1992): Reproductive Biology of the Mare: Basic and applied aspects. $2^{\text {nd }}$ ed. Equiservices, Cross Plains, Wisconsin; 476,500,505

Glatzel, P. S. and Belz, J. P. (1995): Fertility in mares after disturbed or undisturbed puerperium; evidence from clinical, microbiological and hormone analysis. Berl Münch Tierärztl Wochensch; 108, 376-379.

Gygax, A. P., Ganjam, V. K. and Kenney, R. M. (1979): Clinical, microbiological and histological changes associated with uterine involution in the mare. J Reprod Fert Suppl; 27, 571-578

Huhtinen, M., Reilas, T. and Katila, T. (1996): Recovery rate and quality of embryos from mares inseminated at the first post-partum oestrus. Acta Vet Scand; 37, 343-50

Katila, T., Koskinen, E. and Oijala, M. (1988): Evaluation of the post partum mare in relation to foal heat breeding: I. Rectal palpation, Vaginoscopy and ultrasound scanning. J Vet Med A; 35, 92-100

Lowis, T. C. and Hyland, J. H. (1991): Analysis of post-partum fertility in mares on a thoroughbred stud in southern Victoria. Austr Vet J; 68, 304-6

Loy, R. G. (1980): Characteristics of postpartum reproduction in mares. Vet Clin North Am Large Anim Pract; 2(, 345-359

Perkins, N. R. (1999): Equine reproductive pharmacology. Vet Clin North Am Equine Pract; 15, 687-704

Provencher, R., Threlfall, W. R., Murdick, P. W. and Wearly, W. K. (1988): Retained fetal membranes in the mare: a retrospective study. Can Vet J; 29, 903-910

Threlfall, W. R., Provencher, R. and Carleton, C. L. (1987): Retained fetal membranes in the mare. Proc Ann Conv Am Assoc Equine Pract; 649-656

Threlfall, W. R. (1992): Retained placenta. In: Equine Reproduction $1^{\text {st }}$ ed, Ed AO McKinnon, JL Voss, Lea \& Febiger, Philadelphia; 614-621

Steven, D. H., Jeffcott, L. B., Mallon, K. A., Ricketts, S. W., Rossdale, P. D. and Samuel, C. A. (1979): Ultrastructure studies of the equine uterus and placenta following parturition. J Reprod Fertil; 27, 579-86

Vandeplassche, M., Spincemaille, J. and Bouters, R. (1971): Aethiology, pathogenesis and treatment of retained placenta in the mare. Equine Vet J; 3, 144-147

Vandeplassche, M., Spincemaille, J., Bouters, R. and Bonte, P. (1972): Die Microretentio Secundinarum bei der Stute. Tierärztl Umschau; 7, 319-324

Vandeplassche, M., Bouters, R., Spincemaille, J., Bonte, P. and Coryn, M. (1983): Observations on involution and puerperal endometritis in mares. Irish Vet J; 37, 126-132

Woods, G. L., Baker, C. B., Baldwin, J. L., Ball, B. A., Bilinski, J., Cooper, W. L., Ley, W. B, Mank, E. C and Erb, H. N. (1987): Early pregnancy loss in brood mares. J Reprod Fert Suppl; 35, 455-459
Dr. Mello Sevinga

Vet. Pract. Mid-Fryslan

Lange Miente 5

8491 BG Akkrum

The Netherlands

Tel.: 0031-566-652008

Fax.: 0031-566-651205

e-mail: sevinga@xs4all.nl 